\title{
Culturable yeasts in meltwaters draining from two glaciers in the Italian Alps
}

\author{
Pietro BUZZINI, ${ }^{1}$ Benedetta TURCHETTI, ${ }^{1}$ Guglielmina DIOLAIUTI, ${ }^{2}$ Carlo D'AGATA, ${ }^{2}$ \\ Alessandro MARTINI, ${ }^{1}$ Claudio SMIRAGLIA ${ }^{2}$ \\ ${ }^{1}$ Dipartimento di Biologia Vegetale e Biotecnologie Agroambientali, Sezione di Microbiologia Applicata, \\ Università di Perugia, Borgo XX Giugno, I-06100 Perugia, Italy \\ E-mail: pbuzzini@unipg.it \\ ${ }^{2}$ Dipartimento di Scienze della Terra 'Ardito Desio', Università di Milano, Via Mangiagalli 34, I-20133 Milan, Italy
}

\begin{abstract}
The meltwaters draining from two glaciers in the Italian Alps contain metabolically active yeasts isolable by culture-based laboratory procedures. The average number of culturable yeast cells in the meltwaters was 10-20 colony-forming units $(\mathrm{CFU}) \mathrm{L}^{-1}$, whereas supraglacial stream waters originating from overlying glacier ice contained $<1 \mathrm{CFU} \mathrm{L}^{-1}$. Yeast cell number increased as the suspended-sediment content of the water samples increased. Basidiomycetous yeasts represent $>\mathbf{8 0} \%$ of isolated strains (Cryptococcus spp. and Rhodotorula spp. were $33.3 \%$ and $17.8 \%$ of total strains, respectively). Culturable yeasts were psychrotolerant, predominantly obligate aerobes and able to degrade organic macromolecules (e.g. starch, esters, lipids, proteins). To the authors' knowledge, this is the first study to report the presence of culturable yeasts in meltwaters originating from glaciers. On the basis of these results, it is reasonable to suppose that the viable yeasts observed in meltwaters derived predominantly from the subglacial zone and that they originated from the subglacial microbial community. Their metabolic abilities could contribute to the microbial activity occurring in subglacial environments.
\end{abstract}

\section{INTRODUCTION}

Yeasts probably represent the most ancient group of eukaryotic organisms, even though comprising a small number of species ( $\sim 700$ actually known). They occur in many natural environments including air, soil, plants, oceans and caverns, although always represented by a relatively small number of living cells (Lachance and Starmer, 1998).

The isolation of yeasts from glacial environments has been reported by Abyzov (1993) who isolated two yeast species, Rhodotorula glutinis and Cryptococcus albidus, from 3000 year old ice drilled in Antarctica, while several species were isolated and classified by Vishniac (1993) from Antarctic soils.

Although the occurrence of culturable bacteria has been documented beneath glaciers in the Swiss Alps (Sharp and others, 1999), Canadian High Arctic (Skidmore and others, 2000) and Southern Alps (Foght and others, 2004), to the authors' knowledge no studies reported the presence of culturable yeasts in these microbial communities. Claims on the presence of eukaryotic organisms in subglacial environments, if substantiated, would be a significant contribution to our understanding of the evolution and potential spread of microbial life in these extreme environments.

As previously underlined (Foght and others, 2004), the subglacial environment is not easily accessible for microbiological analysis. Nevertheless, meltwaters originating from subglacial flow exiting from beneath the termini of glaciers are known to transport particles from the basal environments of glaciers (Skidmore and others, 2000).

In this study, we perform the isolation and characterization of culturable yeasts from meltwaters draining from two glaciers in the Italian Alps.

\section{METHODS}

Two glaciers in the Italian Alps were selected for this study (Fig. 1). Forni glacier (A) is located in Valtellina (Alps Retiche: Ortles-Cevedale group). Its surface measures $13 \mathrm{~km}^{2}$ and it is the widest glacier complex in the Italian Alps. It is composed of three different accumulation basins generating three ice flows, ending in a common terminal plateau (north-exposed) located at $2700 \mathrm{~m}$ a.s.l. The ice in this plateau region has an estimated thickness of about $150 \mathrm{~m}$ and terminates in a unique ice tongue. The maximum extension of Forni glacier was observed in the Little Ice Age (second half of the 19th century), and almost continuous retreat occurred throughout the 20th century, during which time the glacier tongue thinned at an estimated rate of $3-4 \mathrm{~m} \mathrm{a}^{-1}$.

Sforzellina glacier (B) (included in the Ortles-Cevedale group) has a surface area of $0.4 \mathrm{~km}^{2}$ and is a circular glacier, located at $2800 \mathrm{ma.s.l}$. and with an estimated mean thickness of about $30 \mathrm{~m}$. Its front is almost entirely covered by debris. This glacier also shrank significantly during the 20th century. Its morphology is representative of the majority of glaciers in the Italian Alps.

Sampling was carried out in August in two consecutive years (2002 and 2003). Aliquots $(500 \mathrm{~mL}$ ) of meltwater, originating from subglacial flow exiting from beneath the termini of the glaciers (Fig. 2), were sampled using sterile glass bottles. The bottles were immersed in the melt stream while still sealed, and then opened aseptically while still under the water.

Samples of stream water originating from the overlying glacial ice were sampled following the same procedure. A total of about $15 \mathrm{~L}$ of water per glacier per year was sampled. Samples were stored at $4{ }^{\circ} \mathrm{C}$ until analysis.

Isolation and cell counts were carried out by filtering the meltwater samples through $0.22 \mu \mathrm{m}$ cut-off filters (Millipore, 


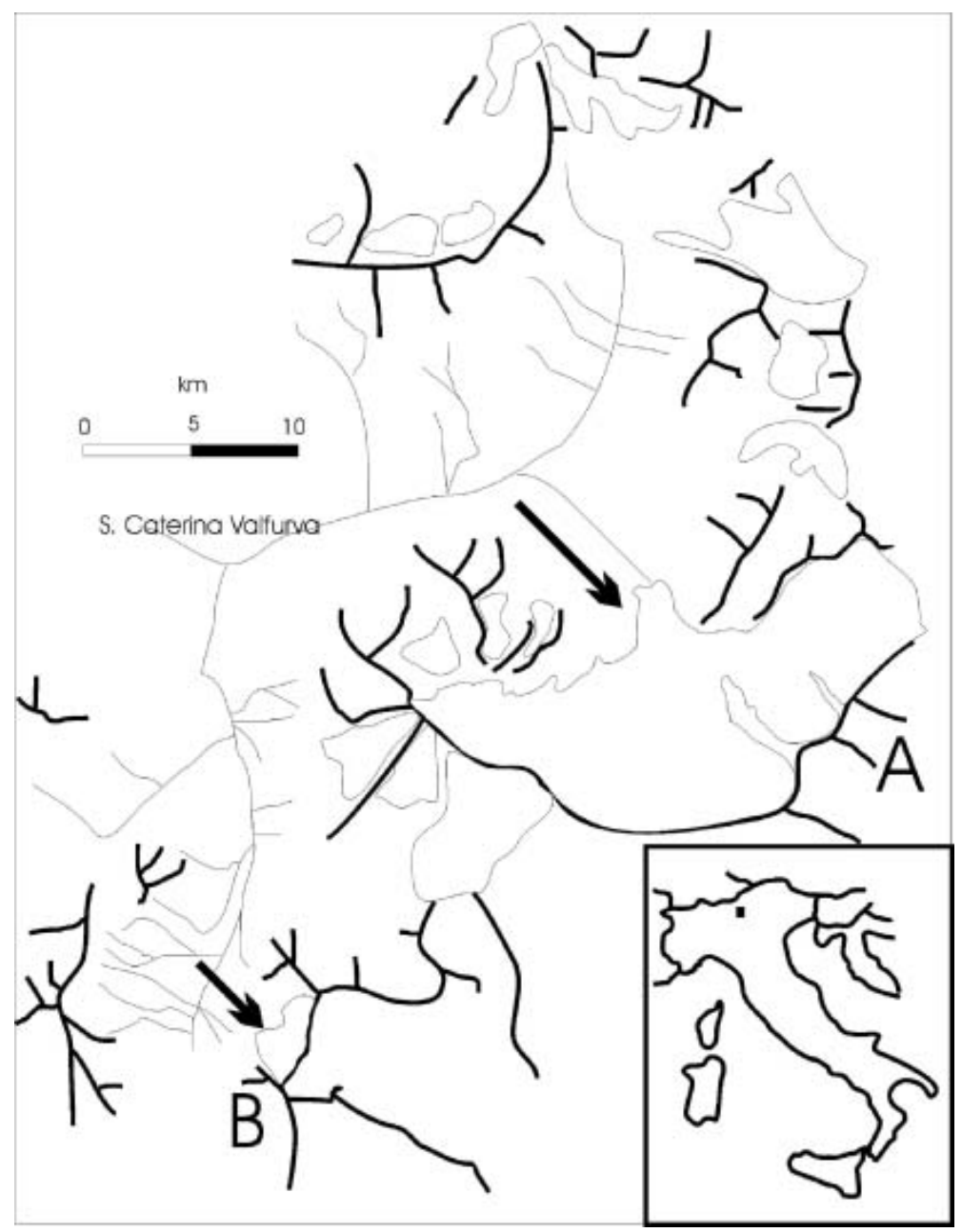

Fig. 1. Location of Forni (A) and Sforzellina (B) glaciers (Italian Alps: Ortles-Cevedale group). The arrows indicate the sampling sites.

USA). Each filter was aseptically cut into two parts, laid down on two Rose Bengal Agar + tetracycline (Difco, USA) Petri dishes, respectively incubated at 20 and $25^{\circ} \mathrm{C}$. Strains were isolated and identified at the genus level by means of conventional morphological, physiological and biochemical procedures according to the latest taxonomic guidelines (Yarrow, 1998). All cultures were included in the DBVPG Collection of Industrial Yeasts of the Dipartimento di Biologia Vegetale e Biotecnologie Agroambientali, Perugia,

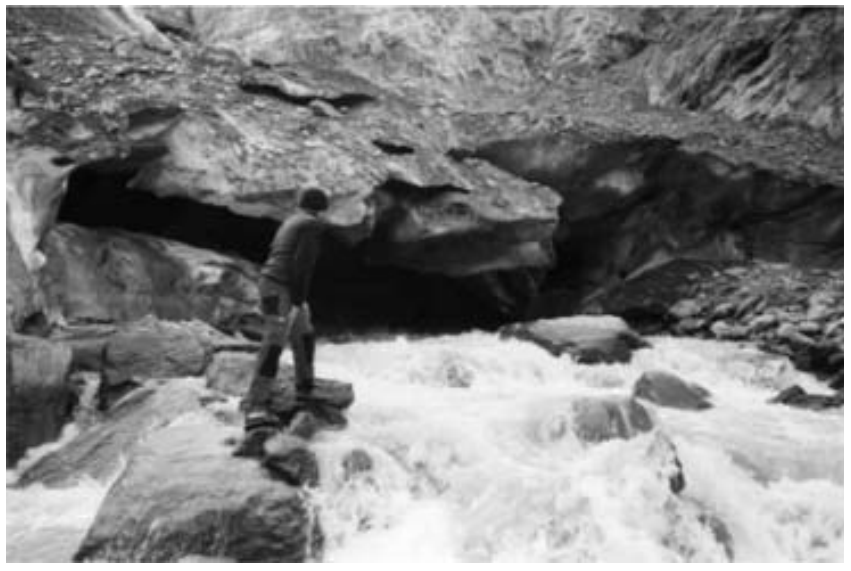

Fig. 2. Meltwaters originating from subglacial flow exiting from beneath the terminus of Forni glacier (August 2002).
Italy (www.agr.unipg.it/dbvpg), and maintained either on YEPG agar $\left(\mathrm{g} \mathrm{L}^{-1}\right.$ : yeast extract 10 , peptone 10 , glucose 20, agar 15) slants or on potato dextrose agar (Atlas and Parks, 1993) slants at $4^{\circ} \mathrm{C}$.

In order to explore whether culturable yeasts can contribute to the metabolic activity of microbial communities in glacial environments, 41 representative strains were screened for their ability to produce extracellular enzymes degrading organic macromolecules: starch, cellulose, pectin, chitin, esters, lipids and proteins, as previously reported (Buzzini and Martini, 2002).

\section{RESULTS}

The aim of these preliminary experiments was to determine whether culturable yeasts were present in meltwaters. The water samples collected at the termini of the two glaciers contained an average of 10-20 colony-forming units (CFU) $\mathrm{L}^{-1}$ of yeasts isolable by culture-based laboratory procedures. In contrast, stream waters originating from the overlying glacial ice contained $<1 \mathrm{CFU} \mathrm{L}^{-1}$. In addition, we noted that the number of culturable yeasts was apparently proportional to the amount of mineral sediment associated with the water sample.

A total of 90 yeast and yeast-like colonies were isolated and identified. Many of the colonies were pigmented yellow or orange. Basidiomycetous yeasts represent $>80 \%$ of the isolated strains (Cryptococcus spp. and Rhodotorula spp. 
Table 1. Ability of yeasts isolated from ice meltwaters draining from Forni and Sforzellina glaciers to degrade organic macromolecules

Number Starch ${ }^{1}$ Esters $^{1}$ Lipids $^{1}$ Proteins $^{1}$ of strains

$\begin{array}{lccccc}\text { Ascomycetous yeasts } & & & & & \\ \text { Candida spp. } & 3 & 0 & 0 & 1 & 0 \\ \text { Dekkera spp. } & 4 & 0 & 0 & 0 & 0 \\ \begin{array}{l}\text { Pichia spp. } \\ \text { Zygosaccharomyces spp. }\end{array} & 1 & 0 & 0 & 0 & 0 \\ \text { Basidiomycetous yeasts } & & 1 & 0 & 0 & 0 \\ \text { Bullera spp. } & 1 & 0 & 0 & 0 & 0 \\ \text { Bulleromyces spp. } & 1 & 0 & 1 & 0 & 0 \\ \text { Cryptococcus spp. } & 17 & 4 & 13 & 6 & 2 \\ \text { Filobasidium spp. } & 3 & 0 & 2 & 2 & 0 \\ \text { Rhodotorula spp. } & 8 & 0 & 4 & 2 & 0 \\ \text { Trichosporon spp. } & 2 & 0 & 1 & 1 & 0 \\ \text { Total strains } & 41 & 5 & 19 & 12 & 2 \\ & & (12 \%) & (46 \%) & (29 \%) & (5 \%) \\ \end{array}$

${ }^{1}$ Number of strains displaying the ability to degrade the given organic macromolecule.

were $33.3 \%$ and $17.8 \%$ of total strains, respectively) (Fig. 3a). Yeast-like organisms were also isolated $(7 \%$ of total strains) (Fig. 3b), whereas $\sim 12 \%$ of isolates are still under study, because they cannot yet be identified as already known yeast species.

All yeast cultures purified from 20 or $25^{\circ} \mathrm{C}$ Petri dishes were able to grow when they were subcultured at $4^{\circ} \mathrm{C}$, suggesting that they were psychrotolerant. They were able to degrade organic macromolecules (e.g. starch, esters, lipids, proteins) (Table 1$)$. Only a few yeasts $(8 \%)$ were able to grow under anaerobic conditions.

\section{DISCUSSION AND CONCLUSION}

The source waters for this study consisted of subglacial flow exiting from beneath the termini of the glaciers (Fig. 2). Consequently, there is the possibility that yeasts isolated in the course of the present investigation originated from the subglacial environment or from sediments on the ice surface entrained into the meltwaters as they passed through the glacier. However, as substantiated by the paucity of culturable yeasts in superficial waters, it is reasonable to suppose that the predominant part of viable yeast cells originated from the subglacial environment.

Although previous experiments clearly demonstrated the occurrence of bacterial populations (including heterotrophs, nitrate and sulphate reducers, and methanogens) beneath glaciers (Sharp and others, 1999; Skidmore and others, 2000; Foght and others, 2004), the presence of yeasts or filamentous fungi has not previously been reported. The present investigation is the first to report the presence of culturable yeast cells in these subglacial environments.

Vishniac (1993) underlined that, in contrast to temperate or tropical habitats, yeast populations in glacial environments seem to contain a restricted number of genera and species. Although none of these are specific to glacier ice habitats, they are ubiquitous in their occurrence in such habitats. Accordingly, the taxonomic assignment of $>50 \%$ of isolated yeasts as belonging to the ubiquitous genera Cryptococcus and Rhodotorula is in agreement with the above early observation.
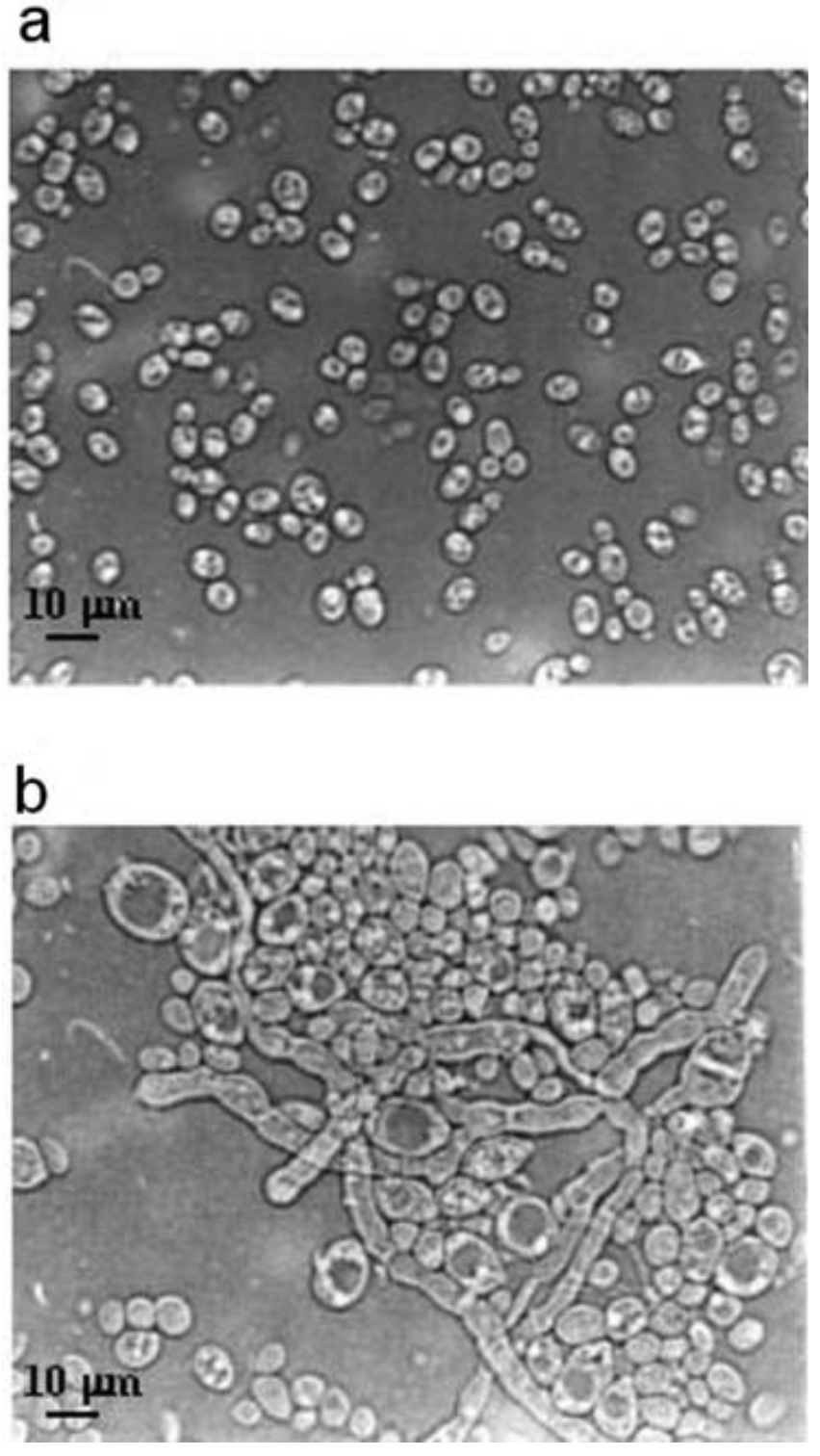

Fig. 3. Microphotographs: (a) strain identified as Rhodotorula spp.; (b) strain identified as yeast-like micro-organism.

The isolation of culturable yeasts from meltwaters suggests that the subglacial environment could harbour viable populations of yeasts which are predominantly aerobic. This seems to be consistent with a previous study (Skidmore and others, 2000) reporting that aerobic microbial growth can occur beneath glaciers. The heterotrophic metabolism of yeasts and their ability to degrade organic macromolecules could suggest their potential role in metabolizing organic carbon and nitrogen. Accordingly, physical and chemical analysis, carried out on some unfrozen sediments from the base of glaciers, indicated the presence of organic matter that could be readily degradable by microbial activity (Skidmore and others, 2000).

The observed relationship between the turbidity of samples and the number of yeast cells implies that culturable yeasts could be associated with the sediments in the meltwaters, similarly to a previous observation (Sharp and others, 1999).

As far as the ecological significance of the presence of yeasts in subglacial microbial communities is concerned, some questions remain open. Due to the inability of most 
microbial species to grow under laboratory conditions using culture-based techniques, the results of this study represent only a partial picture of the yeast biodiversity occurring in subglacial environments. An estimate of what percentage of yeast species is likely to be culturable is, at present, very difficult.

Regarding their biogeochemical function, it remains to be demonstrated that these yeasts are active under in situ subglacial conditions. Further experiments will be designed in the future to determine whether culturable yeasts are present beneath glaciers, and whether they are metabolically active under simulated in situ subglacial conditions.

\section{ACKNOWLEDGEMENT}

The authors are grateful to C. Alese and M. Goretti for their appreciable technical assistance in the course of this study.

\section{REFERENCES}

Abyzov, S.S. 1993. Microorganisms in the Antarctic ice. In Friedmann, E.I., ed. Antarctic microbiology. New York, etc., Wiley and Sons Inc., 265-295.
Atlas, R.M. and Parks, L.C., eds. 1993. Handbook of microbiological media. London, CRC Press.

Buzzini, P. and A. Martini. 2002. Extracellular enzymatic activity in yeast and yeast-like strains isolated from tropical environments. J. Appl. Microbiol., 93(6), 1020-1025.

Foght, J. and 6 others. 2004. Culturable bacteria in subglacial sediments and ice from two Southern Hemisphere glaciers. Microb. Ecol., 47(4), 329-340.

Lachance, M.A. and W.T. Starmer. 1998. Ecology of yeast. In Kurtzman, C.P. and J.W. Fell, eds. The yeasts: a taxonomic study. Amsterdam, Elsevier, 21-30.

Sharp, M., J. Parkes, B. Cragg, I.J. Fairchild, H. Lamb and M. Tranter. 1999. Widespread bacterial populations at glacier beds and their relationship to rock weathering and carbon cycling. Geology, 27(2), 107-110.

Skidmore, M.L., J.M. Foght and M.J. Sharp. 2000. Microbial life beneath a high Arctic glacier. Appl. Environ. Microbiol., 66(8), 3214-3220.

Vishniac, H.S. 1993. The microbiology of Antarctic soils. In Friedmann, E.I., ed. Antarctic microbiology. New York, etc., Wiley and Sons Inc., 297-341.

Yarrow, D. 1998. Methods for the isolation, maintenance and identification of yeast. In Kurtzman, C.P. and J.W. Fell, eds. The yeasts: a taxonomic study. Amsterdam, Elsevier, 77-100. 